\title{
PAYROLL LOANS AND ITS RELATIONSHIP WITH THE AGGREGATE ECONOMIC ACTIVITY (2004-2014)
}

\section{ALINE BEATRIZ SCHUH}

Bachelor in Business Administration from the Department of Administrative Sciences at the Universidade Federal de Santa Maria (UFSM).

Professor at the Instituto Federal de Educação, Ciência e Tecnologia Farroupilha (IFFar). Master's Student in Business Administration at the Universidade Federal de Santa Maria (UFSM). Linha 7 de setembro, BR 386, KM 40, Frederico Westphalen - RS - Brasil - CEP 98400-000 E-mail: abschuh@gmail.com

\section{DANIEL ARRUDA CORONEL}

Doctor in Applied Economics at the Universidade Federal de Viçosa (UFV).

Associate Professor for the Department of Administrative Sciences at the Universidade Federal de Santa Maria (UFSM).

Prédio 74C, Camobi, Santa Maria - RS - Brasil - CEP 97015-900

E-mail: daniel.coronel@uol.com.br

\section{REISOLI BENDER FILHO}

Doctor in Applied Economics at the Universidade Federal de Viçosa (UFV).

Associate Professor for the Department of Administrative Sciences at the Universidade Federal de Santa Maria (UFSM).

Prédio 74C, Camobi, Santa Maria - RS - Brasil - CEP 97015-900

E-mail: reisolibender@yahoo.com.br 


\section{ABSTRACT}

Purpose: Identify the relationship between the granting of payroll loans and macroeconomic aggregates, from 2004 to 2014, through an analysis of the influence of this type of credit on the aggregate economic activity in Brazil.

Originality/gap/relevance/implications: Payroll loans are very representative in the Brazilian credit market, and the discussion on this topic is very extensive, because it is directly linked to the economic growth of a country. However, there is a gap in the literature on this subject, since most studies stress behavioral finances, or the legal aspects of contracts, and also because this type of credit is recent in the Brazilian economy. Key methodological aspects: This is quantitative approach performed through the estimation of the Vector Error Correction Model (VECM), which enabled the computation of impulse-response functions, the variance decomposition and the Granger causality test.

Summary of key results: The results indicate that the granting of payroll loans causes an increase on macroeconomic aggregates in the short term, but over longer periods of time this increase tends to be eliminated. Key considerations/conclusions: The granting of payroll loans influences the behavior of the economic activity. However, despite the fact that its concession provides leverage in the short term, this growth is not sustainable in the long-term. In this scenario, there is exponential growth in household consumption over the past decade; however, the industry productivity and the investments did not follow this evolution. It is inferred from this that the current growth model generates expansion, but its effects are limited.

\section{KEYWORDS}

Payroll loans. Credit market. Macroeconomic aggregates. Brazilian economy. Vector error correction model. 


\section{INTRODUCTION}

The Brazilian financial market currently provides a diverse set of loans and financing to customers who wish to purchase goods or services, but do not have funds available in their personal budget. One of the existing ways to finance these demands is through personal credit, which anticipates resources for individual clients, allowing them to consume immediately and pay for it later, with future income.

Given its applications, it is noteworthy that the access to credit increases the purchasing power of population and, consequently, it fosters the economic activity. This is one of the reasons why the government has, over the last few years, encouraged and eased credit lending, especially to the low-income population. Such changes in the credit policy began in the first term of former President Luís Inácio Lula da Silva (2003-2006), representing a significant change in the economic model that the country had been using for the last twenty years, regarding the granting of credit.

During this period, the concept of microcredit was disseminated, aiming to expand the supply of financial services to low-income populations (Zouain \& Barone, 2008). Within these actions, payroll loans, which were legally instituted by Law n. 10.820 (Brasil, 2003), emerged, authorizing the granting of loans with deductible payments from the payroll of employees covered by the Consolidation of Labor Law (CLT) and also for the holders of retirement and pension benefits of the General Social Security System.

A priori, these actions were promoted to stimulate domestic consumption and boost economic growth from the possibility of an increase in industrial production and in the provision of services, thereby generating more jobs and income. In addition to these actions to popularize credit, in 2003, there was also a great change in the structure and performance of the banking sector, and as a result, the credit-to-GDP ratio, which was reducing until 2002, started to increase (De Paula, Oreiro, \& Basílio, 2013). As a consequence, the credit portfolio in Brazil expanded significantly, increasing from $27 \%$ in 2004 to $54.5 \%$ in 2015 (Banco Central do Brasil, 2015).

The granting of payroll loans possibly was one of the responsible for these changes, since it was part of the policies instituted by the government to stimulate credit, and also, because this type of loan stands out in relation to the other modalities of credit, mainly in relation to the benefits that it offers. In absolute terms, the payroll operations totaled $\mathrm{R} \$ 3.32$ billion in 
September 2014, considering only retirees and pensioners, compared to $\mathrm{R} \$ 7.3$ billion in non-payroll loans, proving that this type of loan became an alternative over the past few years, expanding significantly (Banco Central do Brasil, 2015).

In this sense, analyzing the evolution of payroll loans is a paramount issue, given its current representativeness in the Brazilian credit market, and also because of its role as a mechanism to stimulate the economy. As evidenced by Tristão, Vieira, Ceretta and Bender (2014), the volume of credit granted is a result of the economic situation, which is related to a set of macroeconomic factors. Therefore, in this perspective, the macroeconomic aggregates, such as interest and inflation rates, directly interfere in the supply of credit granted by the financial system.

Considering this context, this study aims to investigate the relationship between credit, specifically payroll loans, and the economic activity in the period after the changes in the credit policy, initiated in 2003. This is accomplished through an analysis of the influence of credit on household consumption, industrial production and investments and on the Gross Domestic Product (Produto Interno Bruto - PIB), providing a greater understanding of the personal credit portfolio in Brazil, specifically in relation to payroll loans, since its emergence and how its concession affected the economic activity.

The discussion about the financial system and the credit market is very broad, mainly because it is directly linked to economic growth. However, the literature on payroll lending is still incipient, especially in the macroeconomic context, since most studies emphasize behavioral finances, or the legal aspects of granting (Marisco \& Fernandes, 2012; Souza, 2013; Neves, 2012). Given this, and taking into account that payroll loans are a recent credit form in Brazilian economy, the proposed approach follows a different line of study, seeking to establish the relationship between the granting of payroll and the macroeconomic aggregates to provide empirical evidence on the effects of this type of credit.

In addition to this introduction, the article is structured in four other sections. In the second section presents the theoretical framework that contextualizes the macroeconomic scenario and the personal credit market in Brazil; in the third section, the methodological procedures are outlined; the fourth section presents the analysis and discusses the results, and, finally, in the fifth section, the conclusions are presented. 


\section{PERSONAL CREDIT MARKET IN BRAZIL: THEORY AND EVOLUTION}

\subsection{Brazilian macroeconomics in the credit market context}

Macroeconomic factors determine the economic performance of a country, which is reflected by measures, such as the Gross Domestic Product, income, consumption, interest rates, and employment level, among others. It is known that, historically, the volume of credit is related to the behavior of these factors and to the decisions involving them, especially the so-called real aggregates. As explained by Tristão et al. (2014), the volume of credit is a result of the economic situation and it is related to a set of macroeconomic factors.

Similarly, according to De Paula et al. (2013), the macroeconomic environment has a key role in determining the offer and the conditions of bank credit. However, because lending is a result of economic conditions, a priori, the decision to expand its concession has impacts on the macroeconomic aggregates, since its main goal is to stimulate consumption, fomenting other sectors of the economy, including industrial production and investments.

One way to evaluate the importance of credit lending is to analyze the relationship between credit and the Gross Domestic Product, since it expresses the representativeness of credit in the economy. In countries where the credit market is underdeveloped, the productive sectors are constrained by the difficulty of financing their operations, and this is one of the reasons why countries with a high credit-to-GDP ratio present more developed economies, such as the United States, England, China and Germany. In Brazil, this rate has grown significantly in recent years, from $23.8 \%$ in 2002 to $54.5 \%$ in 2015. Nevertheless, these figures still leave Brazil behind developed and emerging countries, such as Chile, where, in 2004, the credit already corresponded to $61 \%$ of its product (Federação Brasileira de Bancos, 2006).

Although still relatively low, the relationship between credit and the GDP began to show significant growth in Brazil from 2002, and this behavior can be explained by the changes in the credit granting strategies, and also by the expansion of access to the banking system established in 2003. As a result, in July 2016, the amount of credit granted represented $51.4 \%$ of the GDP (Banco Central do Brasil, 2016).

Thus, as credit lending increased, household consumption expenditure also increased exponentially over the years, due to better working conditions and the improvement of credit market, which influenced consumer expectations. When analyzing the behavior of annual variation of household con- 
sumption expenditure, it is observed that, between 1996 and 2014, although it fluctuates, the index presented a positive evolution. The exception occurred in 2003, when the variation was negative for the four quarters of the year, possibly reflecting the scenario of political uncertainty caused by the change of government (Instituto Brasileiro de Geografia e Estatística, 2015).

However, from 2004 on, the index presented a positive variation until the last quarter of 2014, when it closed the year with a $0.9 \%$ increase compared to 2013. According to Soares (2015), there was a strong expansion of household consumption, especially for those whose main income is derived from the minimum wage.

On the other hand, the first quarter of 2015 presented the lowest performance in household consumption expenditure since 2003, with a negative variation of $0.9 \%$. This recent decline is a reflection of the rise in interest rates and inflation, the reduction in the supply of credit, and the decline in country's economic growth rates, further aggravated by a severe scenario of political instability due to recent corruption scandals.

It is known that when there is an increase in the consumption of goods and services by the population, the industrial production also increases in order to supply the demand of domestic market. In this sense, Cusinato, Minella and Porto (2013) point out that industrial production is one of the most important ways to measure the level of the economic activity, especially because of its ability to internalize both present and future information of the economy.

Historically, as evidenced by Suzigan (1991), Brazilian industrial production was expanded around 1970 due to the expansion of the domestic market and the demand for import substitution investments. Meanwhile, in the 1990s, Brazilian industry underwent a process of economic liberalization, which included the reduction of state intervention and trade liberalization (Bielschowsky, 1999). Since 1994, after the stabilization provided by the Real Plan, economic opening was deepened and the privatization of public enterprises was carried out, which resulted in the restructuring of industry (Bertolli \& Medeiros, 2003).

However, the crisis of 2008 brought a reduction of the industrial production, and the government reacted, lowering interest rates and expanding credit to foster the aggregate demand. Despite this, the increase in the demand for industrial products did not have positive effects on the production, which has not shown significant growth since 2010 and has actually been undergoing successive contractions (Pastore, Gazzano, \& Pinotti, 2012).

The accumulated index of general industrial production in Brazil corroborates this finding, demonstrating that, until mid-1994, the industry showed growth, while after that period it oscillated between small increases 
and decreases and had a significant fall in 2008, as a response to the global crisis. Following the government's measures to deal with the crisis, the index increased slightly from $92.62 \%$ in 2009 to $110.47 \%$ in 2010, but this growth was superficial, because a further decline occurred in 2012, and it reached only $93.4 \%$ in July 2015 (Instituto Brasileiro de Geografia e Estatística, 2015). This scenario of stagnation is in line with Bresser-Pereira and Marconi (2010), who explain that the Brazilian economy has presented, at an early stage, an accumulation of evidences that prove the problem of deindustrialization in the country.

Another way to evaluate the performance of industry and, consequently, the economic growth, is through the measurement of investments in the sector. This measure focuses on the Gross Formation of Fixed Capital (GFCF), which records the expansion of the future productive capacity of an economy through current investments in fixed assets (Instituto Brasileiro de Geografia e Estatística, 2000). In addition, this indicator expresses how much companies invested in capital goods, quantifying the acquisition of equipment, machines and building materials, thus serving as a parameter to identify the evolution of the industrial production.

Considering the last two decades, in 1994, with the introduction of the Real Plan, the GFCF based on production, construction and equipment indexes, showed a positive variation of $14.25 \%$. However, in the following years, the index did not grow much, and it even decreased in some moments (Ipeadata, 2015).

As highlighted by Silva, Rodrigues and Ferreira (2015), the investment index in Brazil, despite rising in some moments, does not present sustainable growth and, thus, the country cannot reach a satisfactory level of investment capable of providing economic growth in the long run. In this perspective, the GFCF, which had a variation of $-11.9 \%$ in the second quarter of 2015, has not presented a positive variation since the second quarter of 2014, confirming the decrease in investments in the industrial sector (Instituto Brasileiro de Geografia e Estatística, 2015).

Differently from the industrial production and the GFCF, the personal credit portfolio in Brazil has been growing steadily in the last few years, mainly due to changes in the banking sector and in the credit policies, as explained in the next section.

\subsection{Evolution of personal credit in Brazil}

The importance of understanding the granting of credit and its mechanisms, as well as its evolution and the role it plays in the economic system is confirmed by the fact that, currently, almost all commercial transactions 
are driven by credit, and the currency plays an accessory function, anchoring credit through government and banking reserves (Furlan, 2009). Because of that, the credit granting is considered essential to the expansion of the economic activity.

Regarding this matter, Costa and Manolescu (2004) complement explaining that credit has an important function in the process of capital accumulation, given its role as a financial transformer, being essential to the operation of the productive sectors and also to the families. In Brazil, both public and private financial institutions are responsible for credit granting and they are able to do this by financial intermediation.

Despite its recognized importance in relation to its role, personal credit was inexpressive until the end of the 1970s, because at that time, people maintained a culture of savings, purchasing mainly in cash or financing in a few installments. It was only after 1994, with the implementation of the Real Plan, that there was a significant increase in the granting of personal credit (Porto, 2013).

The evolution of active personal loan portfolio in Brazil, which includes all loans to individuals, not linked to the acquisition of goods or services is expressed in Graph 1.

\section{(Graph 1)}

\section{BALANCE OF THE PERSONAL LOAN PORTFOLIO WITH FREE RESOURCES BETWEEN MARCH/2007 - MARCH/2015, IN R\$ MILLIONS ${ }^{1}$}
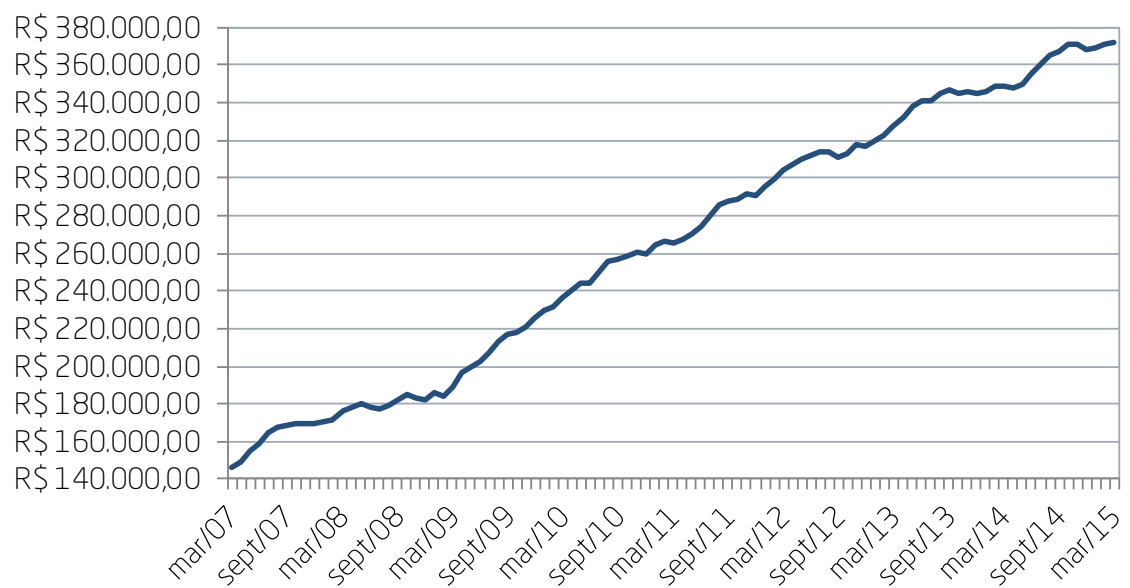

${ }^{1}$ Time series deflated by the General Price Index-Internal Availability (IGP-DI) from the Getulio Vargas Foundation (FGV), based on May 2015. 
In general terms, there is a continuous increase in the granting of personal credit, even after the 2008 crisis. According to Mora (2015), this is mainly due to the countercyclical measures adopted by the government to combat the effects of the crisis, which encouraged the expansion of credit to individuals. In March 2007, the balance of the personal loan portfolio was $\mathrm{R} \$ 146,098$ million, and in the same month, in 2015 , it reached $\mathrm{R} \$ 372,461$ million, representing an increase of approximately $74.5 \%$ in the last eight years.

The exponential growth in the granting of personal credit over the years can be explained mainly by the stabilization of the currency and the significant decrease in inflation in the period after the Real Plan. Banks, until then, were dependent on inflationary revenues, but, because of the changes brought by the Real Plan, they had to direct their actions to the concession of credit as a strategy to maintain their profits, taking advantage of the stimulus to consumption (Soares, 2002).

Another aspect that contributed to this increase was the changes in the credit granting strategies implemented in 2003, when Luiz Inácio Lula da Silva became president. The macroeconomic fundamentals of the previous government were maintained, but the access to credit was expanded, and the concept of microfinance was diffused, mainly through a process called "bancarização" and through the granting of credit by the National Financial System to finance consumer goods and services (Barone \& Sader, 2008).

Moreover, the expansion of credit in this period is due to the confirmation that the new government would not make changes in the economic policy and also because of the lower macroeconomic volatility, as a result of a favorable international scenario and better performance of the external accounts (Freitas \& Prates, 2009). In this context, Figueiredo and Carvalho (2012) highlight that the scenario of lower macroeconomic volatility and the expectation of a reduction in basic interest rates led banks to redefine their operational strategies, prioritizing credit expansion. Also, in 2003, there was a major change in the structure and performance of the banking sector, in addition to the increase in the representativeness of credit in relation to the GDP (De Paula et al., 2013).

Payroll loans emerged within this context, created by Law n. 10,820 in December 2003, which authorized the granting of loans with collateral associated to the payroll of employees covered by CLT and holders of retirement and pension benefits of the General Social Security System.

As a result of these changes introduced by the government, a great expansion of the credit market was observed, but this evolution did not 
occur for all segments. In December 2004, personal loans already represented the largest share of bank loans, with a larger share even than industrial credit (Costa \& Mello, 2006).

Particularly, payroll loans were one of the responsible for the increase in the volume of personal loans granted, mainly due to the great attractiveness that this type of credit offers, both for consumers, due to the low interest rates, and for banks, in view of its guarantees and customer loyalty. Because of that, payroll loans were considered an innovation and grew at an accelerated pace. In mid-2015, its operations totaled R $\$ 268.40$ million, while non-payroll loans totaled $\mathrm{R} \$ 105.77$ million (Banco Central do Brasil, 2015).

Although recent, payroll figures are very significant in relation to the credit market in Brazil. For Barros, Fagundes and Cavalcante (2007), this accelerated expansion trend is mainly due to the fact that payroll loans offer lower interest rates and it is usually offered through aggressive marketing campaigns by financial institutions and also due to the performance of the bank correspondents, which expanded the service network of banks.

\section{METHODOLOGY}

\subsection{Autoregressive vector model}

The Autoregressive Vector (VAR) model consists of a system of equations used to investigate the effects that endogenous variables have on one another, the impact of changes in one variable on the others, and the amount of variance in each variable that can be attributed to changes in each variable itself and in the others (Brandt \& Williams, 2007). Formally, the equation of VAR model, according to Enders (1995), is expressed in (1) and (2):

$$
\begin{aligned}
& Y_{t}=\beta_{10}-\beta_{12} Z_{t}+Y_{11} y_{t-1}+Y_{12} Z_{t-1}+\varepsilon_{y t} \\
& Z_{t}=\beta_{20}-\beta_{21} y_{t}+Y_{21} y_{t-1}+Y_{22} Z_{t-1}+\varepsilon_{z t}
\end{aligned}
$$

assuming that $y_{t}$ e $Z_{t}$ are stationary.

This initial specification shows that the variables are mutually influenced by each other, both in relation to contemporaneous data and to outdated values. Bueno (2008) explains that because the contemporary variables 
$\mathrm{Y}_{\mathrm{t}}$ and $\mathrm{Z}_{\mathrm{t}}$ are individually correlated with the errors $\varepsilon_{\mathrm{yt}}$, and $\varepsilon_{\mathrm{zt}}$, and this model cannot be estimated directly, since each variable depends contemporaneously of each other. Thus, the VAR model aims to correct this problem, finding the trajectory of the variable of interest before a structural shock in the errors.

When performing the modeling of economic series, at first, it is necessary to perform stationary tests in order to verify if the data vary on an average and constant variance or not. To this end, the Augmented Dickey-Fuller test (ADF) was applied, as represented in (3).

$$
\Delta y_{t}=\alpha+\beta_{t}+n y_{t-1} \sum_{i=1}^{p-1}+\lambda_{i} \Delta y_{t-1}+\mu_{t}
$$

the hypothesis are: $\mathrm{H}_{0}: \mathrm{y}=0$, there is a unit root and $\mathrm{H}_{\mathrm{a}}: \mathrm{y}<0$, there is not a unit root.

The null hypothesis of ADF test indicates the presence of a unit root. Thus, the rejection of this hypothesis proves that there is no unit root, confirming that the series is stationary.

The next step consisted in the performance of the cointegration test, which aims to identify if variables have a long-term relationship. This finding was obtained through the Johansen test (Bueno, 2008), formally presented in (4):

$$
X_{t}=\beta_{1} X_{t-1}+\beta_{2} X_{t-2}+\ldots+\beta p X_{t-p}+\delta d_{t}+\varepsilon_{t}
$$

where:

$d_{t}=$ vector with deterministic variables;

$\delta=$ matrix of coefficients, with dimensions compatible with $d_{t}$ of dimension $n m x$.

The confirmation of cointegration between the series and the fact that they are stationary at difference is a necessary condition to estimate the Vector Error Correction Model (VECM). The error correction model is important because it allows the connection between aspects related to short-term and long-term dynamics (Hamilton, 1994). Therefore, it provides a way to combine the advantages of modeling both at level and at differences. Bueno (2008) complements, highlighting that the VECM is a more complete version of VAR model, because when the variables are non-stationary but differentiated, the model omits relevant information, while the VECM model is able to correct such problems. 
In order to estimate the long-term relationship between payroll loans and the independent variables represented by macroeconomic aggregates, the following model was used, as shown in (5).

$$
\begin{gathered}
P L_{t}=\beta_{1} P L t_{-1}+\beta_{2} \text { consumption }_{t-1}+\beta_{3} G F C F_{t-1} \\
+\beta_{4} \text { industry }+\beta_{5} G D P_{t-1}+\varepsilon t
\end{gathered}
$$

Where:

$P L=$ payroll loans granted;

consumption = household consumption;

$G F C F=$ gross fixed capital formation;

$G D P=$ gross domestic product; and

$\varepsilon=$ vector of disturbances.

In order to understand the relationship between payroll loans and the macroeconomic aggregates, impulse-response functions were estimated, since they are able to show the reaction of a variable to an impulse by introducing a shock on each dependent variable. The variance decomposition was also obtained, in order to demonstrate the participation of one variable to explain the behavior of another.

According to Enders (1995), the variance decomposition is able to provide the percentage error of the variance resulting from shocks in the variables. So, if shocks on a variable $z$ can explain the variance of prediction error of variable $y$, then the variable $y$ is endogenous. In this sense, through the decomposition of the variance, it is possible to obtain essential information to verify the importance of a variable to explain the behavior of the others.

Finally, complementing the analysis and aiming to examine the causal relationships between macroeconomic variables and payroll loans, the Granger causality test was performed. Through this procedure, it is possible to verify if the granting of payroll loans precedes changes in the macroeconomic aggregates, providing an auxiliary approach to confirm the relationships discussed in this study.

\subsection{Data source}

After the specification of the empirical model, the collection of data was performed, as detailed in Chart 1. 


\section{(Chart 1)}

DESCRIPTION OF VARIABLES

\begin{tabular}{|c|c|c|c|c|}
\hline Series & Description & Unit & Source & Periodicity \\
\hline $\begin{array}{l}\text { Payroll Loans } \\
\text { Granted }\end{array}$ & $\begin{array}{l}\text { Nominal value of payroll loans } \\
\text { granted by financial institutions } \\
\text { in Brazil. }\end{array}$ & Millions (R\$) & Bacen & Monthly \\
\hline $\begin{array}{l}\text { Household } \\
\text { Consumption }\end{array}$ & $\begin{array}{l}\text { Final consumption expenditure } \\
\text { on goods and services performed } \\
\text { by households. }\end{array}$ & Millions (R\$) & Ipeadata & Quarterly \\
\hline $\begin{array}{l}\text { Gross Fixed } \\
\text { Capital Formation }\end{array}$ & $\begin{array}{l}\text { Additions of durable goods to the } \\
\text { inventory of companies, designed } \\
\text { for productive units. }\end{array}$ & Millions (R\$) & Ipeadata & Quarterly \\
\hline $\begin{array}{l}\text { Industrial } \\
\text { Production Index }\end{array}$ & $\begin{array}{l}\text { Index of industrial production, based } \\
\text { on the monthly industrial survey } \\
\text { of physical production. }\end{array}$ & $\begin{array}{c}\text { Percentage } \\
(\%)\end{array}$ & Ipeadata & Monthly \\
\hline GDP & $\begin{array}{l}\text { Gross domestic product at current } \\
\text { values. }\end{array}$ & Millions (R\$) & Bacen & Quarterly \\
\hline
\end{tabular}

Source: Elaborated by the authors.

In order to develop the proposed methodological procedures, the following variables were used: 1 . payroll loans granted; 2 . household consumption; 3. GFCF; 4. index of industrial production; 5. GDP. All data cover the period from January 2004 to December 2014. The household income and employment rates, which are considered relevant variables, were not included in the model, but are represented as proxies by the GDP and household consumption, respectively.

Regarding the collection of data, there was not a single time series available for the volume of payroll loans granted, covering the entire period. So, those values were extracted and compiled from the monthly credit reports released by the Brazilian Central Bank. The other data were obtained as historical time series from the Ipeadata and Bacen databases.

It is also important to clarify that the payroll loans and the industrial production index time series originally had a monthly periodicity and were converted to quarterly. Also, all variables represented in monetary values (R\$) were deflated, eliminating the effect of inflation, through the General Price Index-Internal Availability (IGP-DI) from the Getúlio Vargas Foundation (FGV), based on May 2015. 


\section{DISCUSSIONS OF RESULTS}

The results of the influence of the concession of payroll loans on the economic activity were obtained from the performance of the set of procedures. First, the ADF stationarity test was carried out, both at level and at first difference, as expressed in Table 1.

\begin{tabular}{|c|c|c|c|c|}
\hline \multirow{3}{*}{ Variables } & IS OF THE & JF STATION & RITY TEST & \\
\hline & \multicolumn{2}{|c|}{ At level } & \multicolumn{2}{|c|}{ At first difference } \\
\hline & $\tau_{t}$ & $\tau_{\mu}$ & $\tau_{t}$ & $\tau_{\mu}$ \\
\hline Payroll loans & -0.201582 & -2.560236 & $-7.792290^{\star \star \star}$ & $-7.689758^{\star \star \star}$ \\
\hline Household consumption & -0.841466 & $-3.509728^{\star}$ & $-3.356417^{\star \star}$ & $-3.312761^{*}$ \\
\hline GFCF & -1.188618 & -0.431760 & $-9.963028^{* \star *}$ & $-10.05750^{* * *}$ \\
\hline Industrial production & -1.764858 & $-3.763983^{\star \star}$ & $-3.762623^{\star \star \star}$ & $-3.732316^{\star \star \star}$ \\
\hline GDP & -1.446835 & -2.956818 & $-3.364065^{\star \star}$ & $-3.579282^{\star \star}$ \\
\hline
\end{tabular}

$\tau_{t}$ represents the analysis with constant; $\tau_{\mu}$ represents the analysis with constant and trend.

$\star \star \star \star, ~ * \star *, *$ represent significance levels of $1 \%, 5 \%$ and $10 \%$, respectively.

Source: Elaborated by the authors.

The Dickey-Fuller test indicates that practically all series did not have unit roots (i.e. they are stationary), when estimated at first difference, for the model with constant and trend and with constant only. As for the consumption and industrial production index series, they were stationary at level.

The following procedure was carried out to determine the length of lags, in order to identify the optimal number of lags. The results are shown in Table 2.

\section{(Table 2)}

RESULTS OF THE TESTS TO DETERMINE THE LENGTH OF LAGS

\begin{tabular}{ccccccc}
\hline Lag & LogL & LR & FPE & AIC & SC & HQ \\
\hline 0 & -1730.307 & NA & $3.18 \mathrm{e}+33$ & 91.33194 & 91.54741 & 91.40860 \\
\hline 1 & -1655.835 & 125.4256 & $2.39 \mathrm{e}+32$ & 88.72818 & $90.02101 *$ & 89.18816 \\
\hline & & & & & & \\
\hline
\end{tabular}




\section{(Table 2 (Conclusion))}

RESULTS OF THE TESTS TO DETERMINE THE LENGTH OF LAGS

\begin{tabular}{ccccccc}
\hline Lag & LogL & LR & FPE & AIC & SC & HQ \\
\hline 2 & -1625.870 & 42.58236 & $1.97 e+32$ & 88.46685 & 90.83704 & 89.31014 \\
\hline 3 & -1584.351 & 48.07527 & $1.00 \mathrm{e}+32$ & 87.59740 & 91.04495 & 88.82401 \\
\hline 4 & -1556.296 & 25.10172 & $1.30 \mathrm{e}+32$ & 87.43661 & 91.96152 & 89.04654 \\
\hline 5 & -1495.218 & $38.57543^{*}$ & $4.46 e^{+31^{*}}$ & $85.53779^{*}$ & 91.14005 & $87.53103^{\star}$ \\
\hline
\end{tabular}

* Indicates the length of lags recommended by the criterion.

Source: Elaborated by the authors.

The criteria to determine the length of lags showed different results regarding the maximum number of lags. While the Akaike and the Hannan-Quin criteria indicated the presence of five lags, the criterion of Schwarz indicated the presence of one lag only. Given this divergence, it was decided to use the criterion of Schwarz, because it is considered more robust and parsimonious (Stock, 1994).

Following the stationarity test and the determination of the length of lags, the cointegration test of Johansen was performed, as presented in Table 3.

\section{(Table 3)}

COINTEGRATION TEST OF JOHANSEN

\begin{tabular}{ccccc}
\hline $\begin{array}{c}\text { Number of cointegration } \\
\text { vectors }\end{array}$ & $\begin{array}{c}\text { Auto value } \\
\text { Test }\end{array}$ & $\begin{array}{c}\text { Critical Value } \\
(\mathbf{0 . 0 5 )}\end{array}$ & Trace Test & $\begin{array}{c}\text { Critical Value } \\
(\mathbf{0 . 0 5})\end{array}$ \\
\hline No vector $^{\star}$ & 59.26639 & 33.87687 & 175.4761 & 69.81889 \\
\hline 1 vector at most* & 47.29972 & 27.58434 & 116.2097 & 47.85613 \\
\hline 2 vectors at most* & 32.88348 & 21.13162 & 68.90997 & 29.79707 \\
\hline 3 vectors at most* & 20.24280 & 14.26460 & 36.02649 & 15.49471 \\
\hline 4 vectors at most* & 15.78369 & 3.841466 & 15.78369 & 3.841466 \\
\hline
\end{tabular}

* Denotes the rejection of the null hypothesis at the significance level of 0.05 .

Source: Elaborated by the authors.

The trace test results indicate that the specified model has a maximum of five cointegration vectors at a significance level of $5 \%$. This finding proves the existence of a long-term relationship between the series. This result and 
the fact that the series are stationary at first difference justify the estimation of VECM.

Therefore, aiming to identify what influence payroll loans have on the macroeconomic aggregates, the impulse response functions, which show the reaction (response) of the independent variables in relation to a shock on the dependent variables, were calculated from VECM. In this case, the granting of payroll loans, that is, a change in the concession policies, and how it would impact the aggregate economic activity. The results are shown in the following graph.

\section{(Graph 2)}

\section{RESPONSE OF THE VARIABLES TO A SHOCK ON PAYROLL LOANS}

Response of CONSUPTION to Cholesky

One S.D. PAYROLL LOANS Innovation

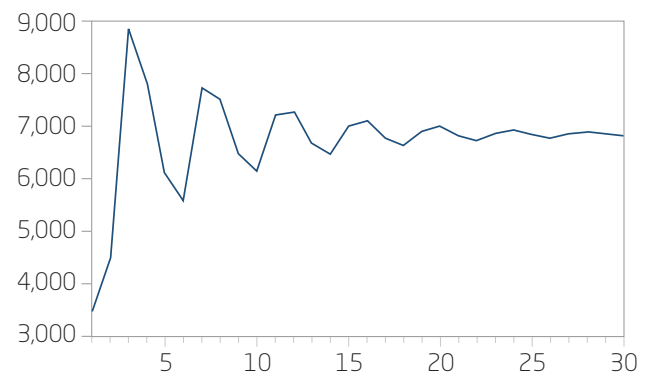

Response of INDUSTRY to Cholesky One S.D. PAYROLL LOANS Innovation

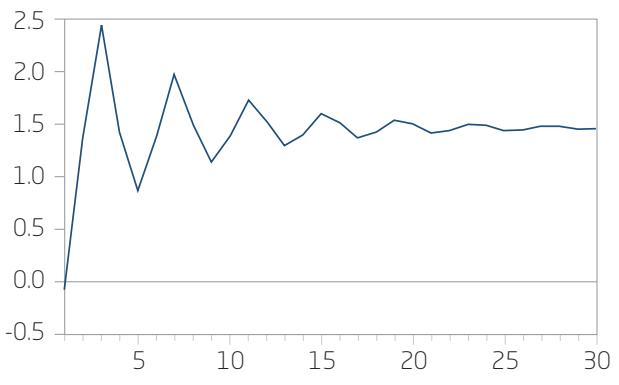

Response of GFCF to Cholesky One S.D. PAYROLL LOANS Innovation

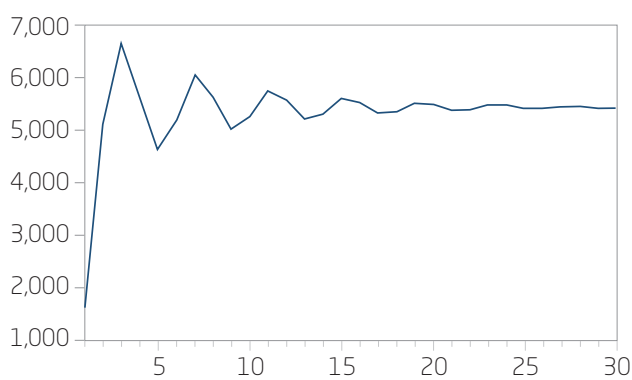

Response of GDP to Cholesky One S.D. PAYROLL LOANS Innovation

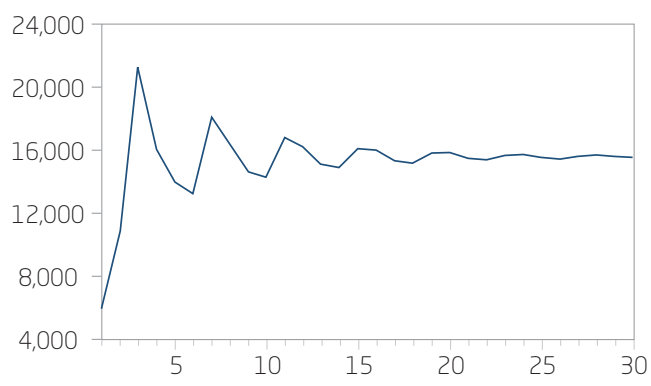

Source: Elaborated by Eviews according to the results.

Analyzing the behavior of the impulse response functions, it is apparent that when a shock is given on payroll lending, household consumption, the GFCF, the industrial production and the product respond positively, with a significant increase in the first quarters. Moreover, it is clear that the 
behavior of all variables have similarities, with a short-term growth, oscillating over the medium term, and stabilizing between the 12th and the 15th period. This suggests that the duration of the direct effects of personal credit policies (payroll loans) are eliminated between 12 and 18 quarters.

Therefore, these results indicate that payroll loans cause an immediate impact on real macroeconomic aggregates, provoking an expansion in the aggregate economic activity. This means that a greater concession generates a short-term acceleration in household consumption and, likewise, the index of industrial production and investments in the sector increase. However, this positive development does not happen in a sustainable way, because its effects are reduced over longer time horizons.

According to De Paula et al. (2013), the granting of credit may be considered cause and consequence of economic growth, because it allows increasing the purchasing power of agents. However, the growth of GDP and income tends to end, from the perspective of demand, precisely because of the credit stimulus. In this sense, although positive, the growth of the personal loan portfolio does not stimulate other types of credit, with longer terms, such as investments in industry and in the agricultural sector. This evidence explains why the granting of payroll loans does not cause a significant impact on long-term economy.

The dynamic responses of household consumption and GDP are in line with the findings of Borça and Guimarães (2015), who analyzed the impact of individual credit in household consumption and found that the share of this type of credit to explain consumption was significant between the years of 2004 and 2007, mainly due to the expansion of the volume granted. In 2008 and 2009, due to the international crisis, the impact on household consumption was lower and, since 2011, has contributed less and less to explain the variations in consumption.

Within this same perspective, Freitas and Prates (2009) highlight that payroll loans, because it has lower interest rates, caused certain changes in the budget of families, allowing the exchange of debts, so families could pay onerous debts with resources from payroll loans. Thus, the cheaper and more accessible credit allowed an increase in consumption by households.

Regarding the industrial production index and the GFCF, although no studies that analyze this relationship were found, the results indicate short-term positive effects, since the increased consumption of goods and services by households tends to be absorbed by larger productive investments or by the existing and unused production capacity of companies. This behavior confirms the instability of Brazilian economic growth rates of recent years that, despite having growth at times, retract subsequently. 
The results exposed above are related to the development of industrial production in Brazil, which did not have experienced significant growth since 2010 and presented a downward trend (Pastore et al., 2012). Similarly, Silva et al. (2015) state that the investment rate in Brazil, in spite of rising at times, does not have a sustainable growth.

Complementing these analyses, the variance decomposition was estimated, from which it was possible to identify the participation of a variable in explaining the variance of others (Vieira \& Cardoso, 2007). Thus, it was possible to examine the participation of payroll loans in explaining consumption, the GFCF, the industrial production and the GDP. The results are shown in Table 4.

\section{(Table 4) \\ VARIANCE DECOMPOSITION OF VARIABLES EXPLAINED BY THE GRANTING OF PAYROLL LOANS}

\begin{tabular}{ccccc}
\hline Period & $\begin{array}{c}\text { Consumption } \\
\text { (payroll loans) }\end{array}$ & $\begin{array}{c}\text { GFCF } \\
\text { (payroll loans) }\end{array}$ & $\begin{array}{c}\text { Industrial } \\
\text { Production } \\
\text { (payroll loans) }\end{array}$ & $\begin{array}{c}\text { GDP } \\
\text { (payroll loans) }\end{array}$ \\
\hline 1 & 5.918171 & 0.174155 & 0.312389 & 2.097618 \\
\hline 3 & 7.012048 & 1.706360 & 6.627712 & 4.263298 \\
\hline 6 & 7.232811 & 2.891974 & 8.022028 & 3.876492 \\
\hline 12 & 10.06900 & 5.374453 & 11.40798 & 6.454565 \\
\hline 24 & 11.12088 & 6.849196 & 12.69414 & 7.388088 \\
\hline
\end{tabular}

Source: Elaborated by the authors.

The variance decomposition shows that in the first period, $5.91 \%$ of household consumption and $2.09 \%$ of the aggregate product forecast errors are explained by payroll loans, while for the other variables, the influence is reduced. However, when analyzing the remaining periods, it appears that the participation of payroll lending increased significantly, and, after 12 periods, the explanation of consumption has doubled, reaching $10.06 \%$. The same was observed for the other variables, but with a more expressive behavior, and the forecast errors explained by payroll loans in relation to the GFCF, the industrial production index and the GDP were $5.37 \%, 11.41 \%$ and $6.45 \%$, respectively. 
Results show that, considering the period of two years, payroll loans continue to expand its participation, greatly in the industrial production index. This situation reinforces the results of the impulse response functions, which demonstrate that the increased availability of credit generates effects on the supply, and also that the most significant changes in the aggregate activity occur in the short term, but in a longer time horizon, and the results tend to be eliminated gradually.

Finally, the Granger causality test was carried out, through which it was possible to confirm that changes in payroll lending precede changes in the macroeconomic aggregates, according to results presented in Table 5.

\section{(Table 5)}

GRANGER CAUSALITY TEST

\begin{tabular}{ccc}
\hline Related Series & F Statistic & Probability \\
\hline Payroll loans $\rightarrow$ Consumption & 5.77519 & 0.0211 \\
\hline Payroll loans $\rightarrow$ GDP & 7.31188 & 0.0101 \\
\hline Payroll loans $\rightarrow$ GFCF & 13.9361 & 0.0006 \\
\hline Payroll loans $\rightarrow$ Industry & 30.4244 & 2. E-06 \\
\hline Consumption $\rightarrow$ Payroll loans & 1.12887 & 0.2946 \\
\hline GDP $\rightarrow$ Payroll loans & 3.48400 & 0.0695 \\
\hline GFCF $\rightarrow$ Payroll loans & 10.5990 & 0.0023 \\
\hline Industry $\rightarrow$ Payroll loans & 17.1596 & 0.0002 \\
\hline
\end{tabular}

Source: Elaborated by the authors.

The rejection of the null hypothesis regarding the causal relationships between payroll loans, household consumption, the GDP, the GFCF and the industrial production show that the granting of credit preceded changes in the macroeconomic aggregates during the period of analysis. These results are in line with the findings of Borça and Guimarães (2015) and Coelho, Mello and Funchal (2012), which show that bank loans were the driver of the aggregate demand in recent years and also influenced the reduction of interest rates and the increase in personal credit lending.

On the other hand, the confirmation of the null hypothesis for the relationship between the macroeconomic aggregates and payroll loans (except for the GFCF and the industry production index) shows that the macroeconomic scenario, with respect to consumption and the GDP, do not precede 
variations in the granting of payroll loans. This occurs because, despite the fact that credit is susceptible to changes in economic conditions, the amount granted is influenced by credit policies, and its results are reflected in the economy.

In summary, the results obtained relate to the empirical evidence and also confirm the important role that payroll loans have been playing as a stimulus to consumption, fomenting other sectors of the economy, especially in relation to the industry, investments and the aggregate product.

\section{FINAL CONSIDERATIONS}

The behavior of the analyzed macroeconomic aggregates showed similar responses to expansions in payroll lending, confirming the sustained discussion in this study, which aimed to demonstrate the existence and the positive direction of the relationship between these variables. To achieve these results, impulse response functions, the variance decomposition and the Granger causality test were estimated from the vector error correction model. Overall, the evidence shows that payroll loans influence the behavior of the economic activity. However, despite the granting of credit provide leverage in the short term, this growth is not maintained and, in the long run, it tends to be gradually eliminated, indicating that the expansion of personal lending policies and more specifically, payroll loans cause positive results, but this scenario is not enough for long term growth.

Discussions about the importance of credit granting to the economy are based on the fact that credit can be a facilitator to finance household consumption and to stimulate the economic activity. Therefore, the exponential growth of household consumption over the past decade is clear, and the period of great expansion coincides precisely with the times when the credit was extended, mainly from the granting of payroll loans.

However, in this scenario, while consumption has increased, the productivity of industries and the investments did not follow this evolution, possibly because lending increase household debt and income commitment due to the increase in consumption. The behavior of the industry also corroborates this conclusion, since the effects on the industry are transient, whereas increases tend to be supplied by the capacity available, and not necessarily by the expansion of the productive structure, which would mean permanent effects and long-term changes. From this context, it is clear that the current growth model generates expansion, but its effects are limited. 
Although the results have shown consistency, allowing the deepening of discussions, it has to be considered as limiting the fact that most of the data used are available on a quarterly basis. This, added to the short period of analysis, due to the fact that payroll loans are a recent credit form, resulted in a relatively small number of observations, so the analysis focused on smaller dispersions.

For future studies, there is the need to assess the impacts of this type of loan on the levels of defaults, focusing on the consequences of using this policy on the economic dynamics. If, on the one hand, payroll reduces the net income of the borrower and may compromise their availability of resources, increasing the risk of default in other operations; on the other hand, it can be used to replace more expensive debts, contributing to a decrease in debt levels.

\section{CRÉDITO CONSIGNADO E SUA RELAÇÃO COM A ATIVIDADE ECONÔMICA AGREGADA (2004-2014)}

\section{RESUMO}

Objetivo: Identificar a relação entre a concessão de crédito consignado e os agregados macroeconômicos reais, no período de 2004 a 2014, a partir de uma análise da influência que essa modalidade de crédito exerce na atividade econômica agregada.

Originalidade/lacuna/relevância/implicações: O crédito consignado possui muita representatividade no mercado de crédito, e a discussão sobre essa temática é muito ampla, por estar diretamente ligada ao crescimento econômico de um país. No entanto, há uma lacuna na literatura acerca do crédito consignado e sua influência na atividade econômica, isso porque a maioria dos trabalhos relacionados a esse tema enfatiza as finanças comportamentais, ou os aspectos jurídicos das contratações, e também porque essa modalidade de crédito é recente na economia brasileira.

Principais aspectos metodológicos: Trata-se de um estudo quantitativo realizado a partir da estimação do modelo Vetor de Correção de Erros (VEC), que possibilitou o cálculo das funções impulso-resposta e a decomposição da variância, além do teste de causalidade de Granger.

Síntese dos principais resultados: O crédito consignado causa uma elevação dos agregados macroeconômicos reais a curto prazo, mas, em períodos de tempo mais longos, essa elevação tende a ser eliminada. 
Principais considerações/conclusões: O crédito consignado influencia o comportamento da atividade econômica. No entanto, apesar de sua concessão proporcionar uma alavancagem no curto prazo, esse crescimento não é sustentável a longo prazo. Nesse cenário, há o crescimento exponencial do consumo das famílias ao longo da última década, todavia a produtividade da indústria e os investimentos não acompanharam tal evolução. Depreende-se, com isso, que o modelo de crescimento atual gera expansão, porém seus efeitos são limitados.

\section{PALAVRAS-CHAVE}

Crédito consignado. Mercado de crédito. Agregados macroeconômicos. Economia brasileira. Vetor de correção de erros.

\section{LA RELACIÓN ENTRE PRÉSTAMOS DE NÓMINA Y LA ACTIVIDAD ECONÓMICA AGREGADA (2004-2014)}

\section{RESUMEN}

Objetivo: Identificar la relación entre préstamos de nómina y los agregados macroeconómicos, de 2004 a 2014, mediante el análisis de la influencia de este tipo de crédito en la actividad económica agregada.

Originalidad/laguna/relevancia/implicaciones: Los préstamos de nómina tienen mucha representación en el mercado de crédito y este tema es muy amplio, ya que está directamente relacionado con el crecimiento económico de un país. No obstante, hay un vacío en la literatura sobre eso, porque la mayoría de los estudios enfatizan las finanzas conductuales, o los aspectos legales de los contratos, sino también, porque este tipo de crédito es reciente en la economía brasileña.

Principales aspectos metodológicos: Estudio cuantitativo, realizado a partir de la estimación del Vector de Corrección de Errores (VEC), lo que permitió el cálculo de las funciones de impulso respuesta, descomposición de la varianza y causalidade de Granger.

Síntesis de los principales resultados: Los créditos de nómina provoca un aumento de los agregados macroeconómicos en el corto plazo, pero a largo plazo este aumento tiende a ser eliminado. 
Principales consideraciones/conclusiones: Los préstamos de nómina influye en la actividad económica. Sin embargo, su concesión proporciona crecimiento en el corto plazo, pero esto no es sostenible a largo plazo. En las circunstancias estudiadas, hay un crecimiento exponencial en el consumo de los hogares en la última década, pero la productividad de la industria y la inversión no siguieron esta evolución. Se infiere que el modelo de crecimiento actual genera la expansión, sino sus efectos son limitados.

\section{PALABRAS CLAVE}

Préstamos de nómina. Mercado de crédito. Agregados macroeconómicos. Economía brasileña. Vector de corrección de errores.

\section{$\int$ REFERENCES}

Banco Central do Brasil (2015). Nota para a imprensa. Retrieved September 10, 2015, from http://www.bcb.gov.br/htms/infecon/notas.asp? idioma=p.

Banco Central do Brasil (2016). Notas para a imprensa. Retrieved 2016, from http://www.bcb.gov.br/htms/infecon/notas.asp? idioma $=$ p.

Barone, F. M., \& Sader, E. (2008). Acesso ao crédito no Brasil: evolução e perspectivas. Revista de Administração Pública, 42 (6), 1249-1267.

Barros, J. O., Fagundes, E. M., \& Cavalcante, L. R. (2007). Spread bancário em operações de crédito consignado no Brasil. Revista Desenbahia, 4(7), 65-85.

Bertolli, S., \& Medeiros, N. H. (2003). Evolução da competitividade da indústria brasileira: uma análise a partir do movimento de reestruturação setorial nos anos de 90. Anais do Encontro Sociedade Brasileira de Economia, Administração e Sociologia Rural. Campo Grande, MT, Brasil, 48.

Brasil (2003). Lei n. 10.820, de 17 de dezembro de 2003. Dispõe sobre a autorização para desconto de prestações em folha de pagamento, e dá outras providências. Brasília, DF.

Bielschowsky, R. (1999). Investimentos na indústria brasileira depois da abertura e do real: o mini-ciclo de modernizações, 1995-1997. Serie Reformas Económicas, 1(44).

Borça, Jr., G., \& Guimarães, D. (2015). Impacto do ciclo expansionista de crédito pessoa física no desempenho da economia brasileira 2004-2013. Revista do BNDES, 1 (43), 119-159. 
Brandt, P. T., \& Williams, J. T. (2007). Multiple Time Series Models. California: Sage.

Bresser-Pereira, L. C., \& Marconi, N. (2010). Existe doença holandesa no Brasil? In L. C. Bresser-Pereira. (Org.). Doença Holandesa e Indústria (pp. 207-230). Rio de Janeiro: FGV.

Bueno, R. L. S. (2008). Econometria de séries temporais. São Paulo: Cengage Learning.

Coelho, C. A., de Mello, J. M. P., \& Funchal, B. (2012). The Brazilian payroll lending experiment. Review of Economics and Statistics, 94(4), 925-934.

Costa, E. A., \& Manolescu, F. M. K. (2004). A importância do crédito na economia. Anais do Encontro Latino Americano de Pós-Graduação. São Paulo, SP, Brasil, 4.

Costa, A., \& Mello, J. (2006). Judicial risk and credit market performance: micro evidence from Brazilian payroll loans. Working Paper Series, 1 (102), 1-42. Cusinato, R. T., Minella, A., \& Porto, Jr., S. da. S. (2013). Produção industrial no Brasil: uma análise de dados em tempo real. Revista Economia Aplicada, 17(1), 49-70.

De Paula, L., Oreiro, J., \& Basílio, F. (2013). Estrutura do setor bancário e o ciclo recente de expansão de crédito: o papel dos bancos públicos. Revista Nova Economia, 23(3), 473-520.

Enders, W. (1995). Applied econometric time series. Estados Unidos: John Wiley \& Sons.

Federação Brasileira de Bancos. (2006). Portal de informações: Módulo I - Crédito. Retrieved September 24, 2015, from https://www.febraban.org.br/ Arquivo/Servicos/Dadosdosetor/modulo-dados-credito-internet.pdf.

Figueiredo, A. T., \& Carvalho, J. N. F. (2012). Expansão do crédito consignado no Brasil entre os anos 2004 e 2011. Informe Econômico - Curso de Ciências Econômicas UFPI, 13(28), 23-27.

Freitas, M. P. de, \& Prates, D. M. (2009). O mercado de crédito no Brasil: tendências recentes. In G. B. Junior, L. F. Novais \& M. P. de Freitas (Orgs.). Panorama das Economias Internacional e Brasileira (pp. 215-234). São Paulo: Fundap.

Furlan, R. C. (2009). A evolução do crédito consignado no estado de Roraima: aspectos econômicos e jurídicos. Dissertação de mestrado, Universidade Federal do Rio Grande do Sul, Porto Alegre, RS, Brasil.

Hamilton, J. D. (1994). Time series analysis. New Jersey: Princeton University Press. 
Instituto Brasileiro de Geografia e Estatística (IBGE) (2000). Sistema de Contas Nacionais. Nota Metodológica, 1 (19), 1-7.

Instituto Brasileiro de Geografia e Estatística (IBGE) (2015). Séries históricas e estatísticas. Retrieved September 30, 2015, from http://seriesestatisticas. ibge.gov.br/.

Ipeadata (2015). Séries históricas. Retrieved September 30, 2015, from http:// www.ipeadata.gov.br/.

Marisco, F. M., \& Fernandes, R. M. P. (2012). A responsabilidade civil na concessão do empréstimo consignado: uma análise do superendividamento do servidor público no estado de Rondônia. Revista de Direito Público, 7(2), 157-180.

Mora, M. (2015). A evolução do crédito no Brasil entre 2003 e 2010. Texto para Discussão / Instituto de Pesquisa Econômica Aplicada, n. 2022.

Neves, R. F. (2012). Efeitos da expansão do crédito consignado ao setor privado no consumo dos domicílios brasileiros. Dissertação de Mestrado, Universidade de São Paulo, São Paulo, SP, Brasil.

Pastore, A. F., Gazzano, M., \& Pinotti, M. C. (2012). Por que a produção industrial não cresce desde 2010? Brasil, economia e governo. Retrieved September 27, 2015, from http://www.brasil-economia-governo.org.br/2012/08/27/por-que-a-producao-industrial-nao-cresce-desde-2010/.

Porto, E. A. (2013). Evolução do crédito pessoal no Brasil e o superendividamento do consumidor aposentado e pensionista em razão do empréstimo consignado. Dissertação de mestrado, Universidade Federal da Paraíba, João Pessoa, PB, Brasil. Silva, R. J. da, Rodrigues, R. L., \& Ferreira, C. R. (2015). Determinantes do investimento agregado no Brasil no período 1995-2013. Economia \& Região, 3(1), 39-56.

Soares, R. P. (2002). Evolução do crédito de 1994 a 1999: uma explicação. Revista PPP Planejamento e Políticas Públicas, 1 (25), 43-87.

Soares, S. D. (2015). Apresentação. In C. A. de Medeiros. Inserção externa, crescimento e padróes de consumo na economia brasileira. Brasília: Ipea.

Souza Jr., E. V. de. (2013). Comportamento financeiro dos servidores do TRT4 frente à oferta de crédito consignado e o risco de superendividamento. Trabalho de conclusão de curso, Universidade Federal do Rio Grande do Sul, Porto Alegre, RS, Brasil.

Stock, J. H. (1994). Unit roots, structural breaks and trends. In R. F. Engle \& D. L. McFadden (Eds.). Handbook of Econometrics, v. 4, p. 2739-2841. Amsterdam: Elsevier. 
Suzigan, W. (1991). A indústria brasileira após uma década de estagnação: questões para política industrial. Sextas Jornadas Anuales de Economia, Montevidéu, Uruguai, 6.

Tristão, P. A., Vieira, K. M., Ceretta, P. S., \& Bender, R. (2014). Evolução do crédito pessoal e habitacional no Brasil: uma análise da influência dos fatores macroeconômicos no período pós-real. Revista Estudos do CEPE, 1(40), 78-106.

Vieira, F. V., \& Cardoso, C. de A. (2007). Câmbio, inflação, juros, reservas na transição de regimes cambiais: uma investigação econométrica para o Brasil. Análise Econômica, 25(48), 23-48.

Zouain, D. M., \& Barone, F. M. (2008). Acesso ao crédito no Brasil: evolução e perspectivas. Revista de Administração Pública, 42 (6), 1249-1267. 